Ігор Кузьмич, кандидат юридичних наук ORCID ID 0000-0002-8646-7271 Олег Розумний, ORCID ID 0000-0003-3225-8375 Національний університет оборони України імені Івана Черняховського

\title{
ПРОБЛЕМИ ОЦІНЮВАННЯ ЯКОСТІ ПРОФЕСІЙНОЇ ПІДГОТОВКИ ВІЙСЬКОВИХ ФАХІВЦІВ
}

У статті розглядаються проблеми оцінювання якості підготовки у вищих військових навчальних закладах Украӥни військових фахівців, узагальнення стану оцінювання якості підготовки військових фахівців та проводиться обтрунтування нових підходів щцодо удосконалення методів, засобів спеціальної підготовки в загальній системі підготовки офічерського корпусу в умовах війни на Сході Украйни.

Ключові слова: оцінка професійної підготовки; Збройні Сили Украӥни; система військової освіти; оцінка якості.

Постановка проблеми. В умовах війни на сході нашої держави загострилися проблеми удосконалення військової професійної освіти, формування професійно підготовленої особистості офіцера, визначення нових напрямків, спеціальностей і кваліфікацій підготовки офіцерських кадрів, здатних грамотно вирішувати складні інженерні, службово-бойові й педагогічні завдання.

Високі вимоги до якості підготовки офіцерів та існуючі проблеми, що заважають розвитку сучасної системи освіти (застаріла навчальноматеріальна база, недостатньо високий рівень підготовки викладацького складу, подвійна, а то й потрійна підпорядкованість військових кафедр, відсутність належного фінансування ВВНЗ, слабкий зв'язок військового навчання 3 життям військ, низька мотивація студентів до військового навчання, відсутність у випускників вузів досвіду практичної роботи на офіцерських посадах тощо), змушують переосмислити місце, мету й задачі підготовки, значення змісту навчального матеріалу дисциплін, що вивчаються на військових кафедрах цивільних вузів, і обгрунтувати нові підходи удосконалення методів, засобів спеціальної підготовки в загальній системі підготовки офіцерського корпусу.

Аналіз останніх досліджень та публікацій. Стратегічними завданнями реформування сучасної військової освіти, визначеними Державною програмою розвитку Збройних Сил України на період до 2020 року, а також професійної підготовки офіцерського складу Збройних Сил України як організаторів бойової підготовки військ $є$ : формування фахової компетентності офіцерів як здатності до якісного виконання своїх професійних функцій за умов переходу на контрактну основу їх комплектування; забезпечення державних потреб у висококваліфікованих, 
відданих справі захисту Батьківщини військових спеціалістах, усебічно та якісно підготовлених до служби у Збройних Силах України призовниках; створення сучасної цілісної, науково обгрунтованої системи військової освіти України для ефективної підготовки військових спеціалістів; використання потенціалу військових навчальних закладів для підготовки спеціалістів із цивільних спеціальностей. Для визначення відповідності офіцерів вимогам, що ставляться державою, Верховним головнокомандуючим Збройних Сил України, Міністром оборони України, військовими статутами та іншими керівними документами, виникає необхідність розробки системи оцінювання якості їх професійної підготовки.

Методи дослідження: узагальнення стану оцінювання якості підготовки військових фахівців у вищих військових навчальних закладах України.

Мета та завдання дослідження. Метою дослідження $є$ визначення стану оцінювання якості підготовки військових фахівців у вищих військових навчальних закладах України в умовах сьогодення та визначення проблем оцінювання якості підготовки військових фахівців у ВВНЗ, шляхів їх вирішення.

Виклад основного матеріалу. Сьогодні найбільш актуальною у середньостроковій перспективі залишається загроза застосування воєнної сили проти України, що обумовлено тимчасовою окупацією РФ Автономної Республіки Крим, м. Севастополя, нарощуванням військової потужності на цих територіях і в безпосередній близькості до державного кордону України, та на частині території Донецької і Луганської областей.

В умовах війни на Сході держави й окупації Криму принципово змінено погляди щодо створення умов для ефективної та якісної підготовки, перепідготовки й підвищення кваліфікації військових фахівців.

У 70-90-х pp. XX ст. питання аналізу якості професійної підготовки випускників, їх готовності до професійної діяльності досліджували педагоги й психологи, зокрема 3 проблем: педагогіки професійної підготовки майбутніх учителів (А. М. Алексюк, I. Д. Багаєва, С.У.Гончаренко, О. А. Дубасенюк, М. Б. Свтух, І. А. Зязюн, Н. В. Кузьміна, О. Г. Мороз, Н. Г. Ничкало, В.В.Сгадова, В.О.Сухомлинський та ін.), психології готовності до вибору професійної діяльності (О. В. Веденов, Г. С. Костюк, В. О. Моляко, В. В. Рибалка, Б. О. Федоришин), готовності до вибору професійної діяльності (С. С. Гриншпун, В. М. Мадзігон, С. М. Павлютенков, В. І. Пуцов та ін.), військової педагогіки (О. В. Барабанщиков, О. П. Багас, М. М. Гречко, А. М. Григор'єв, М. І. Д’яченко, Л. Ф. Железняк, А. М. Зельницький, Л. О. Кандибович, І. С. Колодій, В. С. Маслов, М. І. Нещадим, Г. М. Юхновець, І. О. Хорєв, В. В. Ягупов).

Відмічаємо, що оволодіння критеріями оцінки якості та ефективності досягнутих результатів підготовки є неодмінною умовою успішної роботи викладачів будь-яких типів навчальних закладів. У процесі своєї діяльності педагоги визначають ефективність навчання часто емпіричним шляхом, що не завжди обгрунтовується теоретично, коли до аналітичних операцій вони 
звертаються часто епізодично, також не завжди замислюються над тими шляхами й засобами, які обрали для оцінки результатів пізнавальної діяльності своїх студентів. Тим самим вони часто керуються у своїх діях відчуттями та уявою, що складаються емпіричним шляхом.

Зазначимо, що нині склалася ситуація, яка характеризується, з одного боку, гострою потребою розбудови Збройних Сил України в умовах агресії, підвищення якості підготовки офіцерів, а з іншого - недостатньою науковою розробкою теоретичних проблем і практичної реалізації оцінки якості їх професійної підготовки та професійної готовності.

Відтак, метою статті $є$ обговорення певних теоретичних i практичних підходів до оцінювання якості професійної підготовки військових фахівців.

Оцінка якості професійної підготовки майбутніх офіцерів $є$ основним інструментом контролю, висновків про результативність системи навчання й виховання у ВНЗ. Водночас вона є тим зворотнім зв'язком, на основі якого значною мірою визначається зміст програм і планів навчально-виховної роботи на майбутній цикл.

Отже, оцінка професійної підготовки $\epsilon$ одним із засобів іiі вдосконалення. Знання цієї обставини особливо актуальні тепер, коли йде розбудова Збройних Сил України, у ході якої необхідно досягнути нового якісного стану підготовки військових спеціалістів та впровадження в освітній процес стандартів НАТО.

Слід зазначити, що в багатьох випадках саме відсутність і нестача цих знань, як засвідчує аналіз процесу оцінки якості професійної підготовки, веде до того, що оцінка здійснюється командирами на емпіричному рівні, а це призводить до спотворення результатів, що, зі свого боку, є причиною недооцінки іiі практичної та теоретичної значущості. Крім того оцінку здебільшого пов'язують із кількісною характеристикою результатів професійної підготовки, тобто враховується ii економічний аспект, а це спричинює їі неповноту й однобічність.

Варто сказати, що аналіз наукових джерел, по-перше, підтверджує висновок про функціональну залежність професійної підготовки від оцінки. По-друге, виявляє існуюче в реальній практиці протиріччя між необхідністю оволодіння суб'єктом управління (педагогом) знаннями про оцінку, методологією та методиками іiї проведення й нестачею або відсутністю таких знань взагалі, що значно знижує ефективність професійної діяльності. I, потретє, відображає вимогу реальної практики в постійній оцінці професійної готовності.

Відтак, важливою є розробка системи оцінки професійної підготовки та iii інтегрального показника - професійної готовності. На думку В. О. Бондаренка, оцінка професійної готовності - це один із видів оцінки (підставою такої класифікації виступають об’єкти оцінки) [2]. Тому виявлення iї суті можливе через виділення загального та одиничного. Загальне не існує інакше як в окремому. Отже, немає оцінки взагалі, є лише конкретні види оцінок, що характеризуються як загальним, так і одиничним. 
Такий підхід дає змогу показати сутність оцінки професійної готовності як єдність загального (стійкого) і специфічного (мінливого). Специфічність оцінки професійної готовності полягає у здійсненні оцінки підготовки в системі військової організації. Тому правомірно говорити про іiї особливості, зумовлені загальними для всякого процесу підготовки сентенціями, а також особливості, визначені організацією, у якій вона здійснюється.

Велике значення для розкриття проблеми оцінки якості професійної підготовки та професійної готовності мають роботи В.О.Бондаренка, В. Брожика, Б. К. Морозникова, у яких знайшли своє відображення напрямки загальної теорії оцінки. При цьому не можна не погодитися 3 позицією В. О. Бондаренка, який у розкритті суті, функцій оцінки, пї місця й ролі в діяльності офіцера виходить із того, що найбільш суттєвим матеріальним аналогом оцінки, схожим із нею за структурою і процесом здійснення, виступає вимірювання [2]. П. Н. Городов розглядає оцінку як: а) чинник формування особистості; б) показник відповідності досягнутого рівня виховання поставленим цілям; в) засіб оптимізації педагогічного впливу [3].

Зазначимо, що досвід практичної діяльності викладачів ВВНЗ засвідчує, що у процесі підготовки майбутніх спеціалістів оцінка їх професійної підготовки та професійної готовності здійснюється в результаті порівняння, співставлення знань про реальну професійну готовність із тими, що мають місце в суб' єкта підготовки, уявленнями про те, якою вона має бути. Отже, оцінка професійної готовності - це результат порівняння, оскільки, як відомо, усе пізнається в порівнянні.

Так, В. О. Бондаренко, розкриваючи сутність оцінки, вказує, що «...цинка - це процес і результат відображення одних явищ дійсності шляхом зіставлення, порівняння їх уявлених образів з іншими, засвоєними на практиці й укорінених у свідомості явищами. В оцінці відображається співвідношення, зв'язок декількох явищ, процесів. Якісна й кількісна визначеність одних явищ та процесів використовується в оцінці для вираження цінності, рівня, ступеня, якості, значимості інших явищ, процесів» [2].

Відтак, сутність оцінки полягає в тому, що вона показує специфічне ставлення суб'єкта до об'єкта, унаслідок чого відбувається процес порівняння з іншими об'єктами на основі його пізнання та можливого вибору цього об' єкта як засобу задоволеної потреби.

Таким чином, аналіз публікацій у цій галузі дає змогу зазначити, що існуючі методики мають ряд недоліків і суперечностей [1]. По-перше, при описі методологій оцінки професійної готовності здебільшого не розрізняють рівні ієрархії. По-друге, у методиках, що пропонуються різними авторами, як правило, відсутня необхідна методологічна єдність, на їх основі важко або навіть неможливо порівнювати професійну готовність між різними об'єктами. По-третє, у викладенні методик, зазвичай, відсутні необхідні повнота й логічна злагодженість. По-четверте, методики, що існують, оцінюють не весь комплекс професійної готовності, а лише окремі ії грані. 
По-п'яте, недостатньо розроблені етапи та процедури оцінки професійної

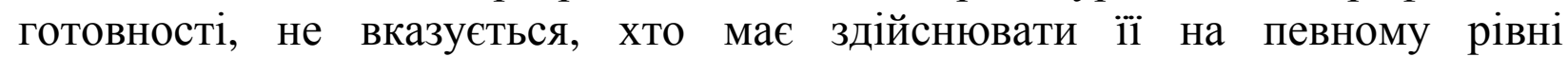
управлінської ієрархії. І, по-шосте, багато авторів не враховують соціальні, психологічні, педагогічні та економічні фактори управлінської діяльності.

Сьогодні в теорії управління недостатньо розкривається зміст та сутність такого важливого елементу процесу управління як оцінка. Ще досі чітко не визначені ії роль і місце в управлінській діяльності. Слід відзначити, що поняття «оцінка» використовують усі дослідники проблеми оцінювання професійної готовності, але в їх роботах воно має досить обмежене смислове навантаження. Одні науковці його розглядають як один 3 етапів функції контролю, другі - як одну з базових операцій, що виконують управлінці, а треті виділяють іï в окрему управлінську функцію, інші - взагалі вживають як синонім слова «вимірювання» тощо. Усі ці факти свідчать про недостатне теоретичне обгрунтування значущості оцінки як однієї 3 детермінант підвищення ефективності професійної діяльності. Відтак, реальний процес оцінювання професійної готовності, як показує практика, більш змістовний та багатогранний, ніж це зазначається в літературі. Між тим багато 3 його граней не знаходить свого теоретичного висвітлення ні в загальній теорії оцінок, ні в оцінці управління загалом, ні в оцінці окремих його сторін [4; 5].

Досвід практичної діяльності суб'єктів управління засвідчує, що оцінка якості професійної підготовки та професійної готовності - це завжди порівняння, хоча не кожне порівняння є оцінкою. Воно є можливим при дотриманні не менше двох вимог. Порівнюватися мають реальні предмети, що цьому піддаються. Тому необхідно визначити реальну величину професійної готовності майбутніх спеціалістів, тобто відобразити iii у визначених поняттях, а потім порівняти з тією ефективністю, що задовольняє потреби суб' єкта, відображені в поняттях. Отже, другою вимогою є наявність необхідного еквівалента оцінки (щоб було з чим порівнювати), а також даного в певних поняттях. Еквівалентом тут можуть виступати науково обгрунтовані уявлення суб'єкта оцінки про кінцевий результат процесу управління, яким має бути цей процес.

Висновки. Узагальнюючи зазначене вище, можна дійти висновку, що оцінка якості професійної підготовки та професійної готовності як іiі інтегрального результату - це специфічне ставлення суб'єкта, виражене в понятійній формі, до реального значення професійної готовності, унаслідок чого відбувається порівняння цього значення з еквівалентом на основі вибору його як критерію задоволення потреби у високих результатах професійної діяльності.

У цілому результати проведеного аналізу, по-перше, підтверджують висновок про функціональну залежність якості професійної підготовки та професійної готовності від їх оцінки, по-друге, вони переконливо розкривають існуючу в реальній практиці суперечність між необхідністю оволодіння суб'єктом управління знаннями про оцінку, методикою іiі здійснення й нестачею або відсутністю таких знань взагалі, що значно 
знижує ефективність професійної діяльності, по-третє, відображає вимогу реальної практики до постійної оцінки професійної готовності спеціалістів.

\section{ЛІТЕРАТУРА}

1. Федоренко В. А. Философско-социологические вопросы воинского воспитания. Ж. : ЖВУРЭ ПВО, 1994. - 232 с.

2. Бондаренко В. А. Оценка, ее место и роль в деятельности офицера. - М. : ВПА, 1987. -39 с.

3. Городов П. Н. Оптимизация процесса воспитания в высшей военной школе. - М. : ВПА, 1983. - $123 \mathrm{c}$.

4. Кубіцький С. О. Оцінка ефективності вищого навчального закладу // Нова педагогічна думка. - 1999. - № 2 (18). - С. 88-92.

5. Кубіцький С. О. Підходи до оцінювання ефективності підготовки майбутніх офіцерів та їх сутність // Соціалізація особистості. - Київ : НПУ. - 1999. - Випуск спеціальний. - С.170-180.

\section{REFERENCES}

1. Fedorenko, V. A. (1994) Philosophical and sociological issues of military education [Philosophical-sociological questions of military education]. - Zh. : ZhVURE PVO (in Ukrainian).

2. Bondarenko, V. A. (1987) Otsenka, ee mesto y rol v deiatelnosty ofytsera. [Assessment, its place and role in the activity of an officer]. - Moscow : VPA (in Russion).

3. Horodov, P.N. (1983) Optymyzatsyia protsessa vospytanyia v vыsshei voennoi shkole. [Optimization of the upbringing process at the higher military school]. - Moscow : VPA (in Russion).

4. Kubitskyi, S. O. (1999) Pidkhody do otsiniuvannia efektyvnosti pidhotovky maibutnikh ofitseriv ta yikh sutnist [Evaluation of the effectiveness of higher education]. New pedagogical thought, № 2 (18). - S. 88-92. (in Ukrainian).

5. Kubitskyi, S. O. (1999) Pidkhody do otsiniuvannia efektyvnosti pidhotovky maibutnikh ofitseriv ta yikh sutnist [Approaches to assessing the effectiveness of training future officers and their essence ] Socialization of personality. - Kyiv : NPU - Issue special. - S.170-180. (in Ukrainian).

\section{PЕЗЮМЕ}

Игорь Кузьмич, кандидат юридических наук,

Олег Разумный

Национальный университет обороны Украины имени Ивана Черняховского

В статье рассматриваются проблемь оценки качества подготовки в высших военных учебных заведениях Украинь военных специалистов, обобщения состояния оценивания качества подготовки военных специалистов и проводится обоснование новых подходов совершенствования методов, средств специальной подготовки в общей системе подготовки офицерского корпуса в условиях войны на Востоке Украины.

Ключевые слова: оченка профессиональной подготовки; Вооруженные Силь Украины; система военного образования; оченка качества. 
Igor Kuzmich,

Candidate of sciences Law,

Oleg Rozumnui

National Defense University of Ukraine named

after Ivan Cherniakhovskyi

\section{Problems of education in the field of professional training in the Faculty of Education}

Introduction. High requirements for the quality of officers training and existing problems that impede the development of a modern system of education (outdated educational and material base, insufficient high level of training of teaching staff, double, and even triple subordination of military departments, lack of adequate funding of the Secondary Education, weak link of military training with the life of troops, low motivation of students for military training, lack of graduates with experience in practical work at officer positions, etc.), make rethink the place, $m$ the ethos and tasks of preparation, the meaning of the content of the discipline studied at the military departments of civilian higher educational institutions, and to justify new approaches for improving the methods and means of special training in the general system of training the officer corps.

Methodos. Generalization of the evaluation of the quality of training of military specialists in higher military educational institutions of Ukraine.

Purpose. The purpose of the study is to determine the state of the evaluation of the quality of training of military specialists in higher military educational institutions of Ukraine in the present conditions and to determine the problems of assessing the quality of training of military specialists in the secondary schools and ways of their solution.

Exposition of basic material. Assessing the quality of future officers training is a key tool for monitoring, conclusions about the effectiveness of the system of education and education in higher education institutions. At the same time, it is the backlink, on the basis of which, to a large extent, is defined as the content of programs and plans of educational work for the future cycle.Hence, the assessment of professional training is one of the means of improving it. Knowledge of this circumstance is especially relevant nowadays when the Armed Forces of Ukraine are developing, in the course of which it is necessary to achieve a new qualitative state of training of military specialists and the introduction of NATO standards in the educational process.

Origenality. Analysis of certain theoretical and practical approaches to assessing the quality of professional training of military specialists.

Conclusions. The results of the analysis confirm the conclusion about the functional dependence of the quality of professional training and professional readiness from their assessment; and secondly, they convincingly reveal the contradiction between the need to master the knowledge of the assessment of the subject, the method of its implementation and the lack of such knowledge in general, which in practice significantly reduces the efficiency of professional activity; Thirdly, it reflects the requirement of real practice to continuously evaluate the professional readiness of specialists. 